\title{
VPLIV UNIVERZE NA RAZVOJ LJUBLJANE
}

\author{
Mirko Pak ${ }^{*}$
}

\section{Izvleček}

UDK $911.375=863(497.4$ Ljubljana)

Univerza v Ljubljani, ustanovljena leta 1919, vključije 27 fakultet in visokih šol ter nekaj umetniških akademij s skupno 33000 študentov. Po drugi svetovni vojni je edina slovenska univerza vplivala na razvoj Ljubljane:

- njene ustanove zavzemajo precejšen del mestnih površin in so poseben element mestnega razvoja (prostorsko in funkcijsko), kar je razvidno iz njihove lokacije;

- $\quad$ zaposlenimi in študenti je pomembno zaznamovala gospodarsko strukturo mesta;

- vključena je v družbeno-kulturno strukturo mesta;

- vplivala je na zgostitev raziskovalnih kapacitet in ustanov z njihovimi znanstvenimi in raziskovalnimi dejavnostmi.

Ključne besede: Univerza, mesto, urbanistično planiranje, Ljubljana.

\section{THE INFLUENCE OF UNIVERSITY ON THE DEVELOPMENT OF LJUBLJANA}

\section{Abstract}

The University of Ljubljana, founded in 1919, includes 27 faculties and higher schools, as well as some academies of art, with 33,000 students altogether. After the $2^{\text {nd }}$ World War, the only Slovenian University influenced the development of Ljubljana for many years:

- its institutions occupy a significant part of town areas and represent some specific elements of town development (spatial and functional), which is evident from their locations;

- it has significantly influenced with its employees and students the economic structure of the town;

- it is integrated in the socio-cultural structure of the town;

- it has influenced the concentration of research capacities and institutions with its scientific and research activities.

Key words: University; Town; Urban planning; Ljubljana.

\footnotetext{
* Dr., prof., Oddelek za geografijo, Filozofska fakulteta Univerze v Ljubljani, Aškerčeva 2, SI 1000 Ljubljana, Slovenija
} 


\section{UVOD}

Univerza je stara inštitucija, ki je $\mathrm{v}$ vsem svojem razvoju na pomenu in pojavnosti le pridobivala. Čeprav najpogosteje mislimo na njeno intelektualno in izobraževalno funkcijo, pomeni $v$ vseh porah socialnega, ekonomskega, kulturnega, znanstvenega, regionalnega življenja in razvoja pomemben, $\mathrm{v}$ številnih sredinah pa temeljni funkcionalni in razvojni dejavnik. Po svetu so univerzitetna središča vodilni razvojni poli, ustanavljanje novih univerz po Evropi v šestdesetih in sedemdesetih letih pa je bilo največkrat namenjeno podpiranju regionalnega razvoja. Poučen primer tega je prestrukturiranje Porurja. Končno se mesta ponašajo s svojimi univerzami in pridevnik "univerzitetno" mesto nekaj pomeni ne le v kulturi, znanosti, intelektualni sredini in imidžu mesta, temveč tudi v poslovnem svetu globalnih razsežnosti.

Univerza niso le študentje in učitelji ter drugo osebje, univerza pomeni tudi številne druge vzporedne inštitucije, obsežno infrastrukturo, prostor, promet, potrošnjo in v srži obsežno ekonomijo. Še posebej novejši čas prinaša univerzi izzive in probleme, ki zahtevajo njeno neposredno vključevanje $v$ gospodarske tokove oziroma tržno gospodarstvo. To zahteva njeno drugačno organizacijo ter vključevanje $\mathrm{v}$ mesto, regijo in državo. To so bili razlogi, da je Univeza v Amsterdamu organizirala marca 1966. leta zelo širok mednarodni simpozij $\mathrm{z}$ naslovom Urban Universities and their Cities. Ob tej priložnosti je nastala tudi osnova pričujočemu prispevku o Univerzi v Ljubljani in mestu. (Pak, 1966)

Tudi v Ljubljani je Univerza znatno vplivala na družbeni, gospodarski in prostorski razvoj mesta. Razvoj Ljubljane je temeljil v prvi vrsti na upravnih, trgovskih, prometnih in drugih terciarnih funkcijah, med katerimi je bila visokošolska ena od pomembnejših vse od ustanovitve Univerze 1919 leta. Ker je bila vse do leta 1961, ko je bil visokošolski študij uveden tudi v Mariboru, to edina visokošolska ustanova $v$ Sloveniji, je k njej gravitirala vsa slovenska študentska populacija. Zaradi boljših zaposlitvenih, eksistenčnih in drugih možnosti so številni diplomanti ostajali v Ljubljani. S tem je bil povezan hitrejši in kvalitetnejši razvoj Ljubljane in razvojni razkorak med Ljubljano in drugimi slovenskimi mesti se je večal. Univerza je tudi pogojila nastanek številnih samostojnih znanstveno-raziskovalnih inštitutov, ki formalno še danes niso povezani z Univerzo, funkcionalno pa zelo tesno s pretokom znanja in kadrov ter raznimi posrednimi in neposrednimi oblikami izobraževanja na dodiplomskem ter podiplomskem študiju.

Pomen ljubljanske Univerze je zato seveda mnogo večji $\mathrm{v}$ funkcionalnem kot $\mathrm{v}$ formalnem pogledu, neposredno in posredno pa je na njene delovne, pedagoške in raziskovalne dejavnosti vezanih še veliko več kadrov, infrastrukture, administracije in tudi prostora. Splošni pomen Univerze v mestu se zato v posameznih elementih ujema 
z Braunovimi navedbami o Free University v Berlinu, realno pa gre kar za precejšnje relativne razlike $v$ prid funkcije in pomena ljubljanske univerze (Braun, 1995).

Neposredno se vloga ljubljanske univerze manifestira $v$ rasti števila študentov, $s$ tem povezanim razvojem zaposlenosti na univerzi, $v$ razvoju pedagoško-raziskovalne infrastrukture, $v$ prostorski ekspanziji univerzitetnih ustanov ter v ekonomski zgradbi in razvoju mesta. Veliko sprememb je prinesel že razvoj v drugi polovici osemdesetih let, še hitrejše pa osamosvojitev Slovenije 1991. leta.

\section{NAGEL PORAST ŠTUDENTOV}

Čeprav je evropska orientacija študija ter $s$ tem povezano soočenje s problemi kvalitete, mobilnosti, kompatibilnosti, intenzivnosti in drugega $\mathrm{v}$ visokošolskem izobraževanju prisotno že od srede osemdesetih let, pa je rast števila študentov dodiplomskega in še posebej podiplomskega študija $v$ okviru specialističnega, magistrskega in doktorskega študija najmanj tako izrazit in pomemben proces. Od leta 1975 do 1996 se je število študentov podvojilo od 15.254 na 35.634 , še močneje pa število programov podiplomskega študija. Temu ustrezno se je povečalo tudi število diplomantov dodiplomskega študija za 70,9\%, magistrskega in doktorskega pa celo za več kot štirikrat. Visoke raste nista omilila niti povečanje študentov na mariborski univerzi in številnejši odhodi na študije v tujino.

Vzrokov za tolikšno povečanje je več, prednjačijo pa potreba prakse po visokošolsko izobraženih kadrih, povečan splošni interes za študij, pa tudi težave z delovnimi mesti. Pred letom 1990 mnogo močneje limitirano število študijskih mest v dodiplomskem študiju, ki pa je bil mnogo bolj kot danes podprt s štipendijami, se je močno povečalo. Povečano število študentov podiplomskega študija pa gre $v$ veliki meri na račun akcije "2000 mladih raziskovalcev", s čemer bi obogatili slovenski znanstvenoraziskovalni potencial. To je močno povečalo tudi število zaposlenih na univerzi in na številnih raziskovalnih inštitucijah. Samo število učiteljev se je povečalo od 847 1980. leta na 1585 leta 1994 , kar pomeni skupaj z mladimi raziskovalci na drugih inštitucijah veliko v razvoju mesta (Rezultati, 1995).

Neposredno se je to manifestiralo $\mathrm{v}$ hitrem ustanavljanju inštitutov in rasti števila zaposlenih $\mathrm{v}$ njih, $\mathrm{v}$ širjenju infrastrukture in $\mathrm{v}$ pritisku na stanovanja $\mathrm{v}$ mestu in okolici. Mladi pedagoški in raziskovalni delavci so številni med kandidati za neprofitna stanovanja, pa tudi pri adaptacijah podstrešij v mestnem središču.

Po letu 1990 se je samo v šestih letih število študentov povečalo za 42,5\% oziroma za $7,7 \%$ letno, od teh rednih le za $31 \%$, izrednih pa kar za $137 \%$. Porast slednjih gre v 
veliki meri poleg splošnih gospodarskih trendov pripisati spremenjeni šolski zakonodaji, kar je med drugim v zadnjih šestih letih za okrog $60 \%$ povečalo število študentov družboslovnih in naravoslovnih študijev.

Zaradi manjših omejitev vpisnih mest, prevladujoče ženske populacije in zaradi večanja študijskih smeri, se je število študentov najbolj povečalo na družboslovnih fakultetah. Poleg za nekdaj nepopularne študije (bibliotekarstvo, obramboslovje, itd.), za katere so se odprla nova delovna mesta, se je močno povečal interes za študij jezikov, geografije, novinarstva, ekonomije in drugega. Močno povečana državna uprava, pa tudi vrsta drugih državnih in zasebnih iniciativ, povezanih z odpiranjem delovnih mest, so močno povečale povpraševanje po tovrstnih strokovnjakih. Velik del diplomantov se zaposli prav $v$ Ljubljani, kjer potrebe hitro naraščajo, tudi $v$ številnih tujih upravnih in gospodarskih predstavništvih.

Po rasti števila študentov so na drugem mestu zelo razvejani naravoslovni študiji. Skupaj z družboslovnimi se je kazalo tudi za naravoslovje manjše zanimanje $v$ času večje gospodarske recesije koncem osemdesetih let. Povpraševanje po teh kadrih je bilo takrat majhno, brezposelnost znatna in zato za študij ni bilo večjega zanimanja. Obratno velja za kadre tehnične stroke, za katere je bilo v času gospodarske recesije večje zanimanje in zato je bil vpis na bolj prespektivne tehnične študije večji, še posebej računalništva, elektrotehnike. Po osamosvojitvi Slovenije se je stanje obrnilo, saj je tehniške stroke prizadela deindustrializacija $\mathrm{z}$ viškom koncem osemdesetih let, kar se je takoj poznalo pri vpisu na posamezne študijske smeri. Že v obdobju 1970-95 je povečanje števila študentov na tehniških fakultetah zaostajalo za drugimi področji, v zadnjih letih pa je celo nazadovalo.

Še najbolj enakomerno rast števila študentov so doživele medicinske študije. Poprej umirjeno povpraševanje po tovrstnih kadrih se je $v$ zadnjih letih povečalo. Močna privatizacija zdravstva sama zahteva številne kadre, ki zato manjkajo v družbenih zdravstvenih ustanovah. To je zanimanje za študij medicine in število vpisnih mest povečalo.

V Ljubljani pride en študent na 10 prebivalcev, kar opozarja na pomembno funkcijo Univerze $v$ življenju, razvoju in zgradbi mesta. Ker je le 35 - 40\% študentov Ljubljančanov, je velik tudi neposredni vpliv univerze na širšo regijo in na celotni državni teritorij. Pomen Univerze še posebej povečuje okoli 1100 mladih raziskovalcev, ki iz vse Slovenije, pretežno pa iz Ljubljane študirajo magistrski ali doktorski študij na ljubljanski univerzi. Kar $60 \%$ teh je na univerzitetnih ustanovah tudi zaposlenih, preostali pa pretežno na inštitutih. Ob intelektualnem je pomemben tudi ekonomski potencial okrog 1700 učiteljev, sodelavcev in raziskovalcev, $\mathrm{h}$ katerim je treba prišteti še okrog 800 pogodbenih sodelavcev. 
Zaradi rasti števila študentov in sodelavcev, novih, posodobljenih ter vedno bolj aplikativno naravnanih študijskih programov, rasti števila diplomantov, dviga njihove kvalitete in še posebej že $v$ osemdesetih letih začetega načrtnega razvoja mladega znanstvenega naraščaja, se funkcija in pomen univerze nedvomno krepita. S tem sovpadajo njena prizadevanja za večjo avtonomijo, njenega formalnega pomena $v$ slovenski družbi in za porast mednarodnega povezovanja, kar daje dodaten pomenski in kvaliteten prispevek k razvoju Ljubljane.

\section{PROSTORSKI RAZVOJ UNIVERZE}

Za Ljubljano je značilna disperzna razmestitev univerzitetnih ustanov od središča do obrobja mesta, prvenstveno v smeri sever - jug. V glavnem se ujema s časovno rastjo Univerze in predstavlja kompromis med podedovanim stanjem, možnostmi, potrebami in zelo raznolikimi pogledi na prostorski razvoj Univerze. Sicer so na njen prostorski razvoj najbolj vplivali država kot investitor, mesto kot planer razvoja mesta ter Univerza in visokošolski zavodi sami s svojimi heterogenimi pogledi. Materialne posledice tolikšne heterogenosti so tudi štiri temeljne lokacije :

- na južnem robu mestnega središča so različne fakultete, od družboslovnih do tehniških;

- južni rob mesta zasedajo tehnične in naravoslovne fakultete;

- družboslovno središče je na severnem robu mesta;

- na vzhodnem robu mestnega središča pa izstopata Medicinska fakulteta s Kliničnim središčem ter Fakulteta za šport.

$\mathrm{Ob}$ vseh štirih središčih se je razvila tudi potrebna infrastruktura $\mathrm{z}$ močnim težiščem v mestnem središču.

Tolikšna disperznost na štirih osnovnih lokacijah, ki se je začela pogljabljati z gradnjo novih fakultet in inštitutov koncem petdesetih let, zaseda s prek 100 ha površine dejansko in funkcionalno velik del mestnega teritorija. Nekateri osnovni problemi takšne lokacije so naslednji :

- prostorske možnosti ne sledijo naglemu porastu števila študentov;

- pomanjkanje prostora za širitev;

- raztresenost univerzitetnih ustanov;

- neorganiziranost;

- pomanjkanje parkirišč;

- premajhna kapaciteta in razpršenost študentskih domov in $s$ tem povezani problemi racionalnega pedagoškega in učinkovitega raziskovalnega dela. 
Karta 1: Univerzitetne inštitucije v Ljubljani

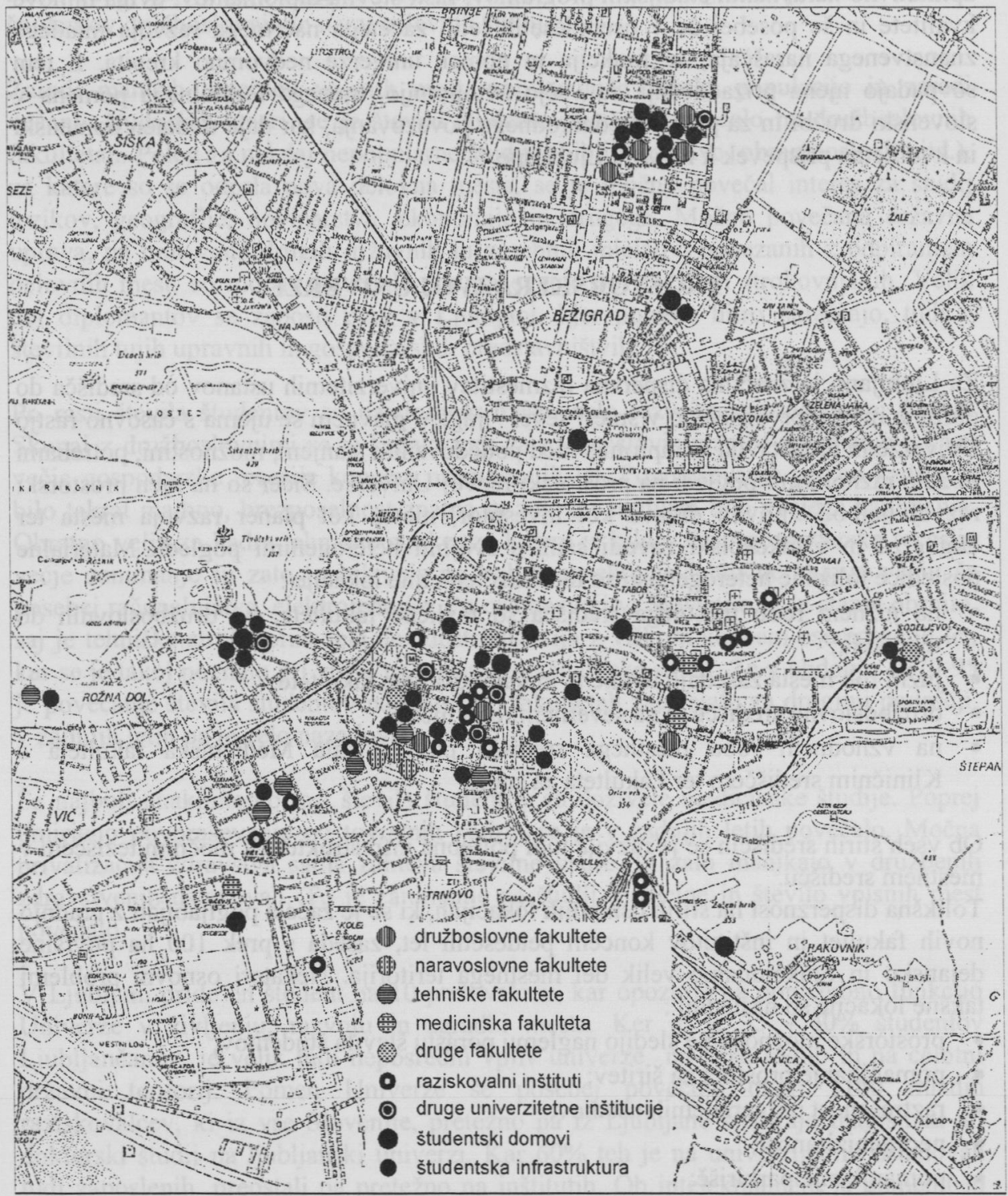


Karta 1 pokaže veliko gostoto univerzitetnih ustanov v Ljubljani, močno razpršenost, pa tudi močno koncentracijo v mestnem središču. Od skupno 26 visokih šol' jih je v središču mesta kar $10 \mathrm{~s}$ posebno močno koncentracijo ob Aškerčevi cesti z najbolj razvejano znanstveno-raziskovalno infrastrukturo (vse pomembnejše knjižnice, galerije in podobno). Leta 1996 je tukaj $49 \%$ študentov obiskovalo družboslovne fakultete, 23\% naravoslovne in $17 \%$ tehniške (Predpisi, 1995). Najstarejši univerzitetni predel, ki je nove fakultetne stavbe dobil po 1960 letu se še nadalje izgrajuje s prizidki, $\mathrm{z}$ novo univerzitetno knjižnico in $\mathrm{z}$ vrsto dislociranih enot, ki se $\mathrm{v}$ mestnem središču še množijo. Zaradi bližine mestnega središča problem študentske infrastrukture ni tako pereč. Pomembna pa je povezava univerzitetnega študija s kulturno funkcijo mesta. Glede na to je očitno, da tudi najnovejši prostorski razvoj Univerze vztraja pri policentrizmu, ki se manifestira $v$ investicijah, ki so po 1991 letu še posebno številne tako $v$ gradnjo novih prostorov, kot $v$ infrastrukturo (Zupančič, 1991).

Lokacija novih fakultet in inštitutov je bila usmerjena na mestno obrobje, kjer je bilo več razpoložljivega zemljišča. To velja za lokacijo tehniških in biotehniških fakultet ter največjih tehniških inštitutov koncem petdesetih in $v$ šestdesetih letih na južnem robu mesta, kjer študira $48 \%$ študentov tehniko in $47 \%$ naravoslovje, kot tudi za družboslovno središče na severnem robu mesta $\mathrm{v}$ sedemdesetih in osemdesetih letih (vse visokošolske ustanove imajo družboslovne smeri). Ker se obe lokaciji še nadalje razvijata in krepita tudi svojo infrastrukturo, postajata funkcionalno tudi $\mathrm{z}$ visokošolskega vidika vedno bolj specifična mestna predela. Sem je šlo v obdobju 1992-1996 kar $70 \%$ od skupno 2432 milijonov tolarjev investicij v ljubljanske univerzitetne ustanove ( $51 \%$ za fakultete in $49 \%$ za študentske domove), za Bežigrad 40,2\% (vključujoč Družboslovno središče) in na Vič 30,9\% (vključujoč Biološko središče). Fakultete $v$ Centru so bile kljub velikim prostorskim problemom deležne le $20,3 \%$ in v Mostah $8,6 \%$ investicij. To pomeni sicer krepitev na severu in jugu mesta, dejansko pa nadaljnje vztrajanje pri razvoju vseh štirih funkcijsko dokaj raznolikih lokacij visokošolskih ustanov in njihove infrastrukture. $\mathrm{Ob}$ tem je zanimivo omeniti še nekatere izstopajoče lokacijske dejavnike, ki so po letu 1990 še pridobili na pomenu. To so v središču mesta humanistične, družboslovne in kulturne ustanove, na jugu sta to velika tehniška inštituta, na severni lokaciji je med drugim to bližina obrambnega ministrstva in vojaških šol, v Mostah pa razvoj Kliničnega centra.

${ }^{1}$ Ljubljanska Univerza združuje 27 fakultet, visokih strokovnih šol in umetniških akademij, med njimi Fakulteto za pomorstvo in promet v Portorožu. 
Karta 2: Struktura študijskih mest Univerze v Ljubljani 1996

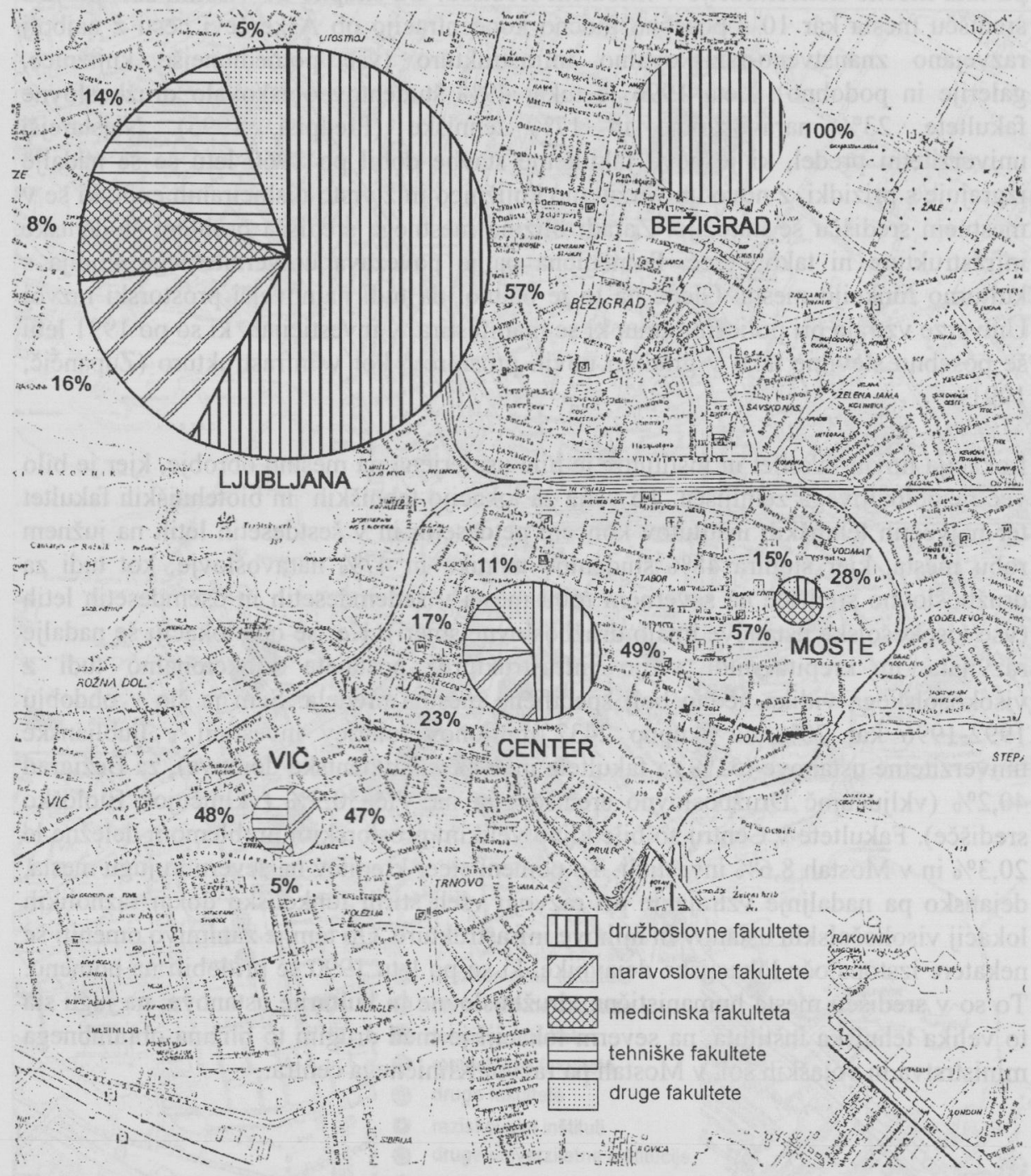


Štiripolarnost univerzitetnih ustanov daje močan funkcionalni, prostorski, ekonomski in socialni pečat vsem štirim lokacijam z rastjo vsakovrstne infrastrukture (od oskrbne do kulturne), s koncentracijo študentske populacije, obremenitvijo prometnih tokov in S samim načinom življenja $\mathrm{v}$ teh specifičnih mestnih predelih, kjer je leta 1996 študiralo naslednje število študentov: za Bežigradom 12500 (37,4\%), v Centru 11274 $(33,7 \%)$, na Viču $5751(17,2 \%)$ in v Mostah $3926(11,7 \%)$.

Policentrični razvoj spremljajo ob številnih, po mestu razpršenih inštitutih in študentski infrastrukturi, tudi študentski domovi. Njihove kapacitete močno zaostajajo za potrebami, čeprav se je število postelj od 1980 do 1996 leta skoraj podvojilo na 6569. Njihova lokacija pa kaže smeri ekspanzije fakultet. Stara lokacija na Viču premore skoraj polovico postelj, novejša na severu skoraj tretjino, ostalo pa lokaciji na jugu in v središču mesta. Velik del študentske populacije je $v$ mestu zelo disperzno nastanjen.

Lokacija nastanitvenih kapacitet $\mathrm{v}$ študentskih domovih, skupaj $\mathrm{z}$ disperzno lokacijo preostalik zasebnih študentskih bivališč, in zgoraj navedena lokacija študijskih mest močno vplivajo tudi na mestne prometne tokove in na prometno obremenjenost mesta, skupaj z dnevno migracijo študirajočih in univerzitetnega osebja iz obmestja pa tudi na širše regionalne prometne tokove in na prometno infrastrukturo.

\section{VLOGA UNIVERZE V RAZVOJU LJUBLJANE}

Univerza $v$ Ljubljani je vse od svoje ustanovitve znaten dejavnik $v$ razvoju mesta, tako z ekonomskega, socialnega in prostorskega vidika. Njen pomen celo narašča, kar kaže vse tesnejše povezovanje Univerze z gospodarstvom, znanstveno-raziskovalnimi inštitucijami, kulturo in drugim. Vprašanje pa je, ali je mesto samo to ustanovo dovolj upoštevalo in jo tudi dejansko podpiralo, kot enega temeljnih dejavnikov njenega razvoja. Da temu ni tako kaže dejstvo, da Ljubljana še vedno ni proglašena za univerzitetno mesto, da do zadnjega časa mesto Univerzi ni posvečalo zadosti pozornosti in z njo sodelovalo na partnerski ravni, kot je to $\mathrm{v}$ navadi pri univerzitetnih mestih sicer. Univerza kot inštitucija $v$ mestnih predstavništvih praktično ni bila prisotna.

V ekonomskem pogledu ustvarja okrog 4000 zaposlenih in 31000 študentov, ter še nekaj tisoč posredno sodelujočih z Univerzo mestu znaten dohodek, povečuje zaposlitev $v$ mestni infrastrukturi in mu prinaša kvalitetnejši razvoj. Poudariti je ob tem treba, da učiteljski kader predstavlja sloj z višjo kupno močjo, ki veliko sredstev nameni tudi $v$ univerzitetnih središčih še posebej poudarjeni kulturni infrastrukturi. Dohodek se sicer ne more primerjati $\mathrm{z}$ deležem tovrstnega dohodka $\mathrm{v}$ znanih evropskih univerzitetnih središčih, vsekakor pa je eden pomembih dejavnikov 
mestnega razvoja. J. Leib navaja, da mesečno porabijo študenti marburške Univerze le nekoliko višji znesek kot porabi ljubljanski študent (Leib, 1994). Delež porabe univerzitetnih delavcev $v$ Ljubljani pa je zaradi njihove ugodnejše socio-ekonomske sestave tudi višji od zaposlenih $v$ večini drugih dejavnosti. Posreden ekonomski učinek je vsekakor kohezija vrste gospodarskih in negospodarskih dejavnosti, ki služijo prvenstveno ali v veliki meri Univerzi.

\section{SKLEP}

Razumljivo je, da so osamosvojitev, ter s tem povezana demokratizacija in tržno gospodarstvo prinesli precejšnje spremembe Univerzi sami in s tem tudi njenemu položaju v družbi in vplivu na razvoj Ljubljane. Glavne spremembe in tendence organizacijskega, vsebinskega in materialnega položaja Univerze so naslednje :

- centralizacija in s tem povečan pomen "Univerze", "večja avtonomija" Univerze, preoblikovanje univerzitetnih organov, formiranje novih visokošolskih zavodov tudi visokih strokovnih šol ;

- porast števila študentov in diplomantov, drastično zmanjšanje štipendiranja, oblikovanje raznih fundacij in prizadevanje za dvig kvalitete študija ;

- zaostrena kadrovska politika - poostreni pogoji za izvolitev profesorjev, mednarodna primerljivost;

- povečanje investicij v Univerzo, več sredstev predvsem za infrastrukturo, nove lokacije, ki naj bi privedle vsaj do prepoznavnega univerzitetnega središča na ravni mesta;

- povečana nuja po dodatnem pridobivanju dohodkov, trženju, menedžmentu visokošolskih ustanov Univerze po vzorcu uspešnih zahodnoevropskih univerz

- krepitev vsesplošnega pomena Univerze $v$ državni prestolnici Ljubljani kot enega pomembnih nosilcev njenega razvoja 


\section{LITERATURA}

- Leib J., 1994: Marburg als Universitaetsstadt. Marburg - Maribor, Marburger Geographische Schriften, Heft 126, Marburg / Lahn, s. 114 - 132.

- Dietz K., Braun G. O., 1994: Reflections between urban and University structure and planning. Managing and Marketing of urban development and urban life. Berlin, p. 1 - 7.

- Pak M., 1996: The influence of the University on development of Ljubljana. Urban Universities and their Cities. Book of abstracts. Amsterdam, p. 46.

- Predpisi v visokem šolstvu. Ljubljana 1990, s. 46 - 47.

- Rezultati raziskovanj, Diplomanti 1970 - 94. Zavod RS za statistiko, Ljubljana 1994.

- Zupančič T., 1991: Ublikacijske možnosti razvoja Univerze v Ljubljani. Ljubljana /Diplomska naloga na Fakulteti za arhitekturo./.

\section{THE INFLUENCE OF UNIVERSITY ON THE DEVELOPMENT OF LJUBLJANA}

\section{Summary}

Like in other university centers, the University in Ljubljana has also had a strong influence on the town's social, economic and spatial development. The development of Ljubljana (320,000 residents), which became the capital only in 1991 when the state gained independence, was based on the administrative, commercial, transport and other tertiary functions, among which higher education has been one of the most important ever since the establishment of the University in 1919. Because all until 1961, when higher education was also established in Maribor, the University of Ljubljana was the only academic institution in Slovenia and the total population of Slovenian students gravitated to this town. Due to better employment, existential and other possibilities, numerous graduates have remained in Ljubljana to live there. This subsequently resulted in a faster and qualitative development of Ljubljana and the gap between this and other Slovenian towns grew deeper. The University also conditioned the establishment of a number of independent scientific-research institutes which are still not related to the University formally, but functionally, they have been collaborating quite intensely all the time, through the exchange of knowledge and experts, as well as through various direct and indirect forms of education on the level of undergraduate and postgraduate studies.

European orientation of study and its related confrontation with the problems of quality, mobility, compatibility, intensity and alike, have already been present in 
higher education since the mid-eighties; however, the increase in the number of students, especially of post-graduate students (specialization, master's and doctoral studies) has become at least as explicit and important process. The number of undergradute students doubled between 1970 and 1995, from 15,254 to 31,266 , and the number of the above mentioned post-graduate students grew even more intensely. Concurrently, the number of graduates adequately increased, by $70.9 \%$, and the number of those who earned their master's or doctor's degrees, increased more than by four times. Neither the increase in the number of students at the University of Maribor nor the students who went to study abroad have mitigated this intense growth in the number of students at the University of Ljubljana.

After 1990, the number of students has increased by $42.5 \%$ within six years only, which is by $7.7 \%$ per year, of which full-time students only by $31 \%$, and part-time students as much as by $137 \%$. The increase in the number of the latter is particularly due to the changes of education legislation, which has also caused that in the past six years, among other things, the number of students of social sciences increased by $75 \%$, and of natural sciences, by $62 \%$.

There comes one student per 10 residents of Ljubljana, which points to an important function of the University in the life, development and structure of the town. Since only $35-40 \%$ of students come from Ljubljana, the direct influence of the University on the wider region and the entire state territory is also great.

The dispersed locations of the University institutions are typical of Ljubljana, running from its center towards the outskirts of the town. They mainly coincide with the growth of the University through the time and represent a compromise between the inherited situation, the possibilities, the needs, and very diverse attitudes to the spatial development of the University. However, this development has been most strongly influenced by the state as the investor, the town as the planning authority of urban development, and the University and its institutions with their heterogeneous needs. The following four basic locations are the materialized result of such heterogeneity:

- the southern edge of the inner city with various faculties, such as of humanities, social sciences and technical sciences;

- the southern outskirts with the faculties of technical sciences and natural sciences;

- the northern outskirts with the center of social sciences;

- the eastern edge of the inner city with the Faculty of Medicine together with the University Medical Center, and the Faculty of Sport.

- The necessary infrastructure, too, has been developed near all four centers.

Along with the numerous institutes and student infrastructure, dispersed throughout the town, students' dormitories, too, are part of the polycentric development. Their capacities lag heavily behind the needs, although the number of beds was almost doubled between 1980 and 1996, i.e. up to 6,569 beds. 
Ever since its establishment, the University of Ljubljana has been an important factor in the development of the town, so from the viewpoint of economy, as from the social and spatial viewpoints. Its significance is further increasing, which is manifested by the ever closer connectedness of the University with economy, scientific-research institutions, culture and other institutes of civil society. Nevertheless, the question emerges, whether or not the town itself has paid enough attention to this institution and has actually supported it. It is questionable why Ljubljana has not been declared a University City, so far. 